\title{
カルバモイルメチルラジカルの環化反応と天然物合成への 応用
}

\author{
石 橋 弘 行*・佐 藤 達 典*・池 田 正 澄* \\ Carbamoylmethyl Radical Cyclizations and Applications to the Synthesis \\ of Natural Products
}

Hiroyuki Ishibashi*, Tatsunori Sato* and Masuzumi IkEdA*

\begin{abstract}
Free radical cyclization is rapidly becoming an important method for the synthesis of cyclic compounds. This review summarizes our recent studies on the synthesis of nitrogen-containing heterocycles by means of cyclization of $N$-alkenic carbamoylmethyl radicals which are generated from the corresponding $\alpha$-haloamides by treatment with tributyltin hydride in the presence of azobis(isobutyronitrile)(AIBN). Ruthenium-catalyzed chlorine atom transfer cyclizations of $\alpha$-chloro- $\alpha$-thioacetamides have also been examined. These reactions are classified into several types of ring closures including relatively difficult 4-exo-trig and 5-endo-trig cyclizations which provide $\beta$ - and $\gamma$-lactams, respectively. Applications of the method to the synthesis of natural products are also presented.
\end{abstract}

Key words : Radical cyclization; Atom transfer cyclization; Carbamoylmethyl radical ; $\beta$-Lactam ; $\gamma$-Lactam ; Pyrrolizidine alkaloid ; Amaryllidaceae alkaloid ; Asymmetric induction ; 5 -Endo-trig cyclization ; 4-Exo-trig cyclization.

\section{1. はじめに}

ラジカルを活性種として用いる反応は他のイオン反応 では得がたい特異な化合物をしばしば与える。しかし， ラジカル反応は一般に複雑な生成物を与えることが多い ため合成化学的に用いられることは比較的少なかった。 ところが, ここ十数年のラジカル反応に関する研究の進 歩には目覚ましいものがある。その理由の 1 つとしては, ラジカル反応を効率的に行う基質が続々と見いだされた ことが挙げられよう1)。また，従来用いられてきた $\mathrm{Bu}_{3} \mathrm{SnH}-\mathrm{AIBN}$ 系を用いる反応の他に, トリエチルボラ ンをラジカル開始剤とする皮応 ${ }^{2)}$ や遷移金属触媒を用い る反応 ${ }^{3)}$ な゙も次々と開発された。

ラジカルを用いる反応の中でも, 分子内アルケンまた はアルキンとの反応による環形成反応は「ラジカル環化 反応」と呼ばれ, 種々の環状化合物の新しい合成手段と

* 京都薬科大学

* Kyoto Pharmaceutical University )

\section{して近年脚光を浴びている。}

筆者らは最近, カルバモイルメチルラジカル 2 が多様 なラジカル環化反応を効率よく行うことを見いだした。 このラジカルは $\alpha$-ハローまたは $\alpha$-チオアミド 1 を AIBN 存在下 $\mathrm{Bu}_{3} \mathrm{SnH}$ で処理するか, 1 をルテニウム触 媒で処理することにより発生させることができる。前者

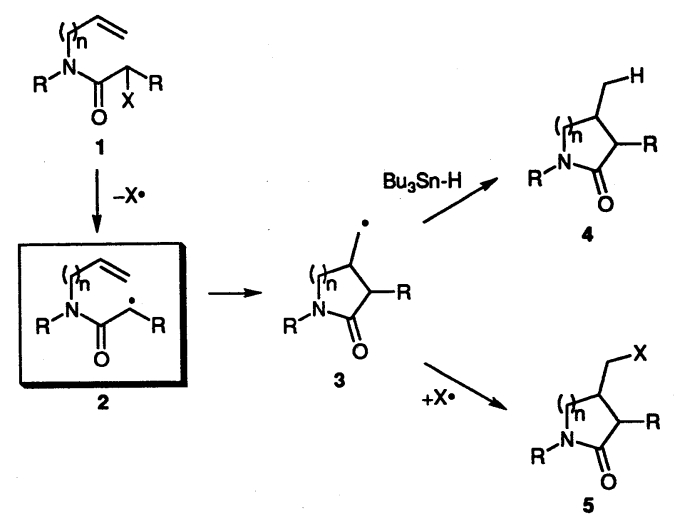

Scheme 1 
の反応では, ラジカル 2 の環化によって生じた中間体 3 が $\mathrm{Bu}_{3} \mathrm{SnH}$ の攻撃を受けて化合物 4 を与える。また, 後 者の反応では, 脱離したハロゲンがラジカル 3 に再結合 することにより化合物 5 を与える。後者の反応は atomtransfer 環化反応と呼ばれている。

本稿では, このカルバモイルメチルラジカルの環化反 応の詳細とその天然物合成への応用についてまとめる。 なお, 天然物合成におけるラジカル前駆体の合成法は誌 面の都合上省略したので，詳細は原著を参照していただ きたい。

\section{5-Exo-Trig 型ラジカル環化反応}

我々が本研究に着手した頃， $\alpha$-ヨードアセトアミド のパラジウム触媒反応 ${ }^{3 a)}$ やトリクロロアセトアミドのル テニウムまたは銅触媒環化反応 ${ }^{3 b}$ を用いる $\gamma$-ラク夕ム の合成は知られていたが， $\alpha$-ハロアミド 1 AIBN 存在 下 $\mathrm{Bu}_{3} \mathrm{SnH}$ で処理することにより発生させる 2 のような フリーラジカルの環化反応については報告例がなかっ た。そこで，まず，常法に従い，化合物 6 a の還流ベン ゼン溶液に $\mathrm{Bu}_{3} \mathrm{SnH}$ と $\mathrm{AIBN}$ のベンゼン溶液をゆっくり 加えたところ，5-exo-trig 型環化反応成績体 7 a が $68 \%$ の好収率で得られることがわかった。その際，未環化の 還元体 $8 \mathrm{a}$ が $16 \%$ の収率で得られた ${ }^{4,5)}$ 。

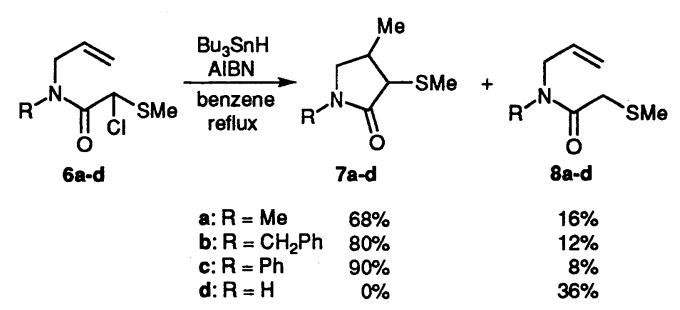

Scheme 2

次に, 窒素原子上の置換基効果を調べるため, 化合物 $6 \mathrm{~b}, \mathrm{c}, \mathrm{d}$ の反応を検討したところ, 窒素原子上の置換 基をベンジル基やフェニル基のように大きくすると環化 体が高収率で得られることがわかった(式 2)。また,

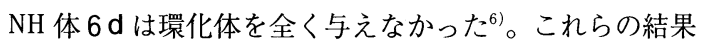
は以下のように説明できる。すなわち, ラジカル前駆体 6 の rotamer には $Z$-rotamer $(6 Z)$ と $E$-rotamer $(6 E)$ が 考えられる。もし, 窒素原子上の置換基 $\mathrm{R}$ がフェニル 基のように大きいと, その置換基とクロロスルフィド部 との立体反発によりアリル基の方がクロロスルフィド側 を向く。すなわち, rotamer $6 Z$ が有利となり, $6 Z$ から 発生したラジカル $9 Z$ はアリル基と環化反応を行うこと
ができる。一方，窒素原子上の置換基 $\mathrm{R}$ が水素のよう に小さいと， $6 Z$ のアリル基とクロロスルフィド部の反 発により, むしろ, rotamer $6 E$ が有利となり，6Eから 発生したラジカル $9 E$ はアリル基と環化反応を行うこと ができない゙

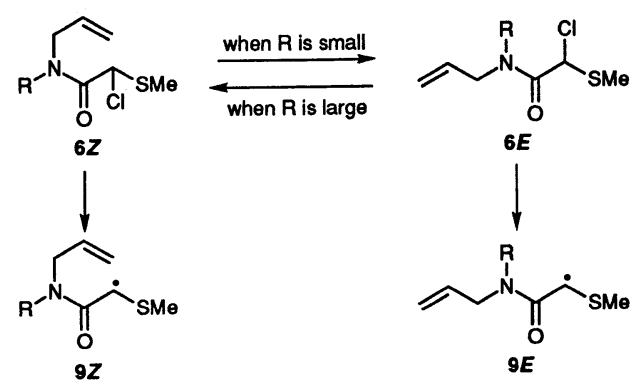

Scheme 3

次に，窒素原子上の置換基をフェニル基に固定し，メ チルチオ $(\mathrm{SMe})$ 基以外のラジカル炭素上の置換基効果を 調べるため化合物 10 の反応を検討した。その結果， ラ ジカル炭素上の置換基 $\mathrm{R}$ としてラジカルを安定化させ る $\mathrm{Me}, \mathrm{Ph}, \mathrm{Cl}, \mathrm{OMe}$ および OAc 基を用いた場合, 環化 体 12 a-e が好収率で得られることがわかった。また， 無置換 $(\mathrm{R}=\mathrm{H})$ とした場合, 環化体 $12 \mathrm{f}$ は $12 \%$ の収率で しか得られなかった。さらに,フェニルスルホニル基を 導入した場合, その前駆体 $10 \mathrm{~g}$ の消失が大変遅く, 化 合物 8 に相当する還元体のみしか得られなかった5)。従 来, ラジカル安定化基によって安定化されたラジカルは アルケン類との反応性にそしいと言われてきたが，これ らの結果はそれに全く反する興味深い結果と言えよう。

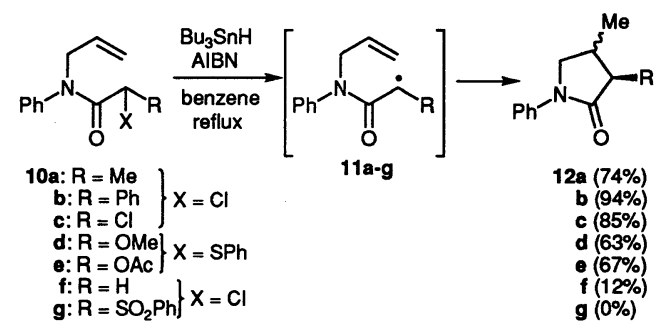

Scheme 4

環化体 $12 \mathrm{c}(\mathrm{R}=\mathrm{Cl})$ は $\mathrm{Bu}_{3} \mathrm{SnH}-\mathrm{AIBN}$ で還元すると $12 \mathrm{f}$ をえることから，12fのような化合物が欲しい場 合には, ジクロロ体 $10 \mathrm{c}(\mathrm{R}=\mathrm{X}=\mathrm{Cl})$ に 2 3 当量の $\mathrm{Bu}_{3} \mathrm{SnH}$ を作用させることにより化合物 $12 \mathrm{f}$ を収率良く 得ることができる。本反応は後述する天然物合成に大変 
有用であった。

\section{3. ピロリジジンアルカロイドの合成}

\section{1. $\mathrm{Bu}_{3} \mathrm{SnH} / \mathrm{AIBN}$ 系を用いる反応}

クロロスルフィド 13 を $\mathrm{AINN}$ 存在下 $\mathrm{Bu}_{3} \mathrm{SnH}$ で処理 したところ, ピロリジジン誘導体 14 が得られた ${ }^{8)}$ 。また, ジクロロ体 15 を 2.2 当量の $\mathrm{Bu}_{3} \mathrm{SnH}$ で処理すると, 化合 物 16 が得られた。

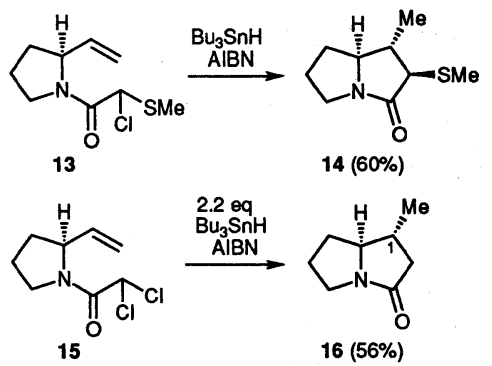

Scheme 5

\subsection{Atom-transfer 環化反応}

$\alpha$-ハロアミドの atom-transfer 環化反応は成績体にハ ロゲン原子が導入されるため合成化学的に大変有用であ る。化合物 13 を $\mathrm{RuCl}_{2}\left(\mathrm{PPh}_{3}\right)_{3}$ 存在下ベンゼン中 $140^{\circ} \mathrm{C}$ で加熱したところ，1位にクロロメチル基が導入された ピロリジジン誘導体 17 が得られた ${ }^{9)}$ 。

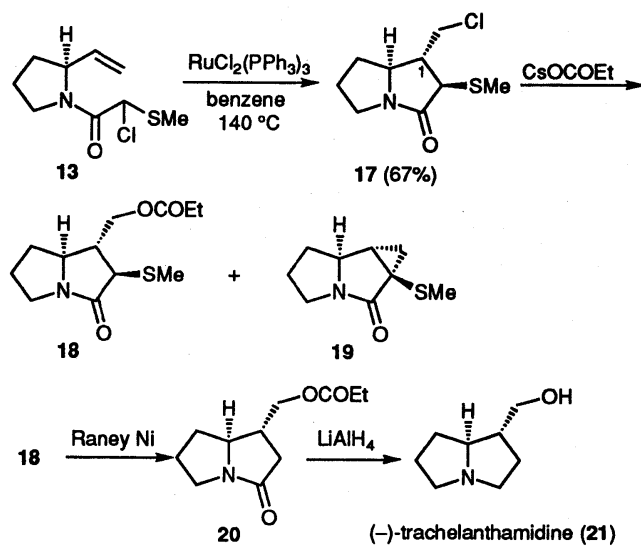

Scheme 6

次に, 化合物 17 18-crown-6 存在下還流クロロベ ンゼン中プロピオン酸セシウムで処理すると, 少量のシ クロプロパン誘導体 19(8\%) とともに置換反応成績体 18 が $73 \%$ の収率で得られた。化合物 18 は化合物 20 を経
て, ピロリジジンアルカロイドの 1 つである(-)trachelanthamidine(21)へと変換することができだ9 。

\section{4. cis-3 a-アリールヒドロインドール骨格を有す} るアルカロイド類の合成

橋頭位 (3 a 位)に芳香環を有する cis-ヒドロインドー ル類は mesembrine, mesembranol(31)など Sceletium ア ルカロイドや haemanthidine(44), pretazettine(45)など クリニン型ヒガンバナ科アルカロイドの基本骨格であ る。筆者らは前述の $\gamma$-ラクタム合成法を利用してこれ らアルカロイド類の合成を行った。

\section{1. (士)-Mesembranol の合成法}

化合物 22 を AIBN 存在下 2.2 当量の $\mathrm{Bu}_{3} \mathrm{SnH}$ で処理 したところ, 環化体 23 が $43 \%$ の収率で得られた。同時 に,フェニル基の転位した成績体 24 も少量 $(6 \%)$ 生成し た ${ }^{10,11}$ 。

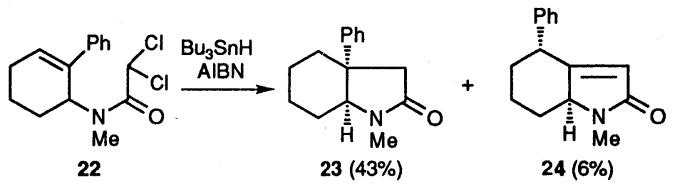

Scheme 7

化合物 24 の生成機構は以下のように考えられる。す なわち，22 から発生したラジカル 25 が5-exo-trig 型の 環化反応を行うと, まず, ラジカル 26 が生じる。次いで, 26 が $\mathrm{Bu}_{3} \mathrm{SnH}$ の攻撃を受けると 23 をえるが, 26 のラ ジカル中心が分子内のベンゼン環を攻撃するとスピロ中 間体 27 を与える。そして, 27 が芳香化すると同時にク ロロ原子を押し出すと転位成績体 24 を学る。

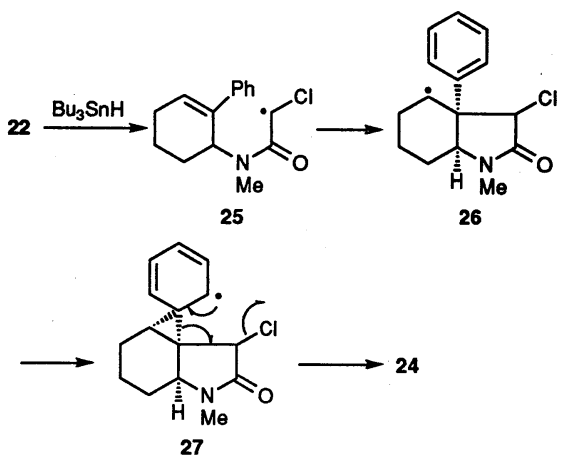

Scheme 8

Mesembranol(31)を合成するためには, ラジカル前駆 体としてアシルアミノ基とベンジルオキシ基が 6 員環上 
でトランス配置を有する化合物 29 が必要である。化合 物 29 は化合物 28 から立体選択的に合成し，これを 2.2 当量の $\mathrm{Bu}_{3} \mathrm{SnH}$ で処理したところ, 環化体 30 が得られ た。次に, 30 のラクタムカルボニル基を還元し, 脱べ ンジル化を行うと $( \pm)$-mesembranol(31)が得られた11)。

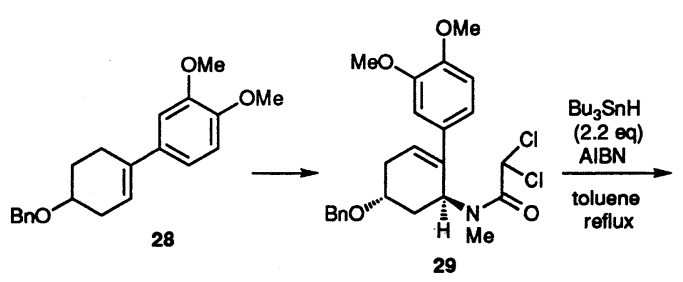<smiles>C=C1C[C@@]2(c3ccc(OC)c(OC)c3)CC[C@@H](Cc3ccccc3)C[C@]12N(C)[Mg]</smiles>

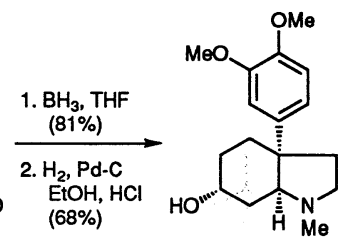

(士)-mesembranol (31)

Scheme 9

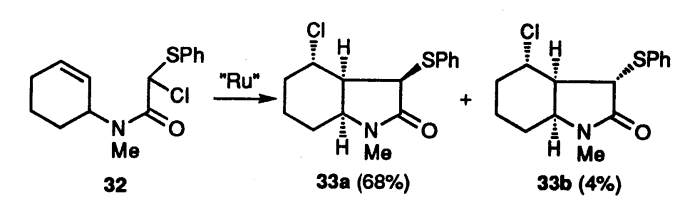

$\overbrace{34}^{\mathrm{Ph}} \mathrm{S}_{\mathrm{O}}^{\mathrm{CPh}}$

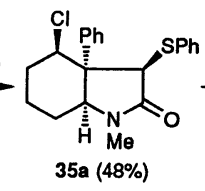<smiles></smiles>

"Ru" = $\mathrm{RuCl}_{2}\left(\mathrm{PPh}_{3}\right)_{3}$

Scheme 10

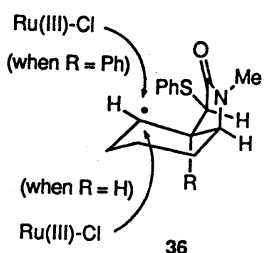

Fig. 1
4.2. (士)-Haemanthidine および(士)-Pretazettine の合成

Pretazettine(45)(式 11)はクリニン型ヒガンバナ科ア ルカロイドの中でも最も複雑な化合物の 1 つであり, 強 い抗ウイルスおよび抗腫瘍活性を有することから，有機 合成化学者にとって格好の合成ターゲットとなってい る。このアルカロイドはその $\mathrm{C}_{1}-\mathrm{C}_{2}$ 位に二重結合を有す るため, 前述の $\mathrm{Bu}_{3} \mathrm{SnH}-\mathrm{AIBN}$ 系を用いるラジカル反応 では合成し難い。そこで，筆者らは $\alpha$-クロロスルフィ ド38の atom-transfer 環化反応を利用する pretazettine の合成を計画した。すなわち，38 から得られるであろ う環化体 39 のクロロ原子を利用して 45 の $\mathrm{C}_{1}-\mathrm{C}_{2}$ 位に二 重結合を導入し，また，フェニルチオ基を利用して $\mathrm{C}_{6 \mathrm{a}}$ 位に酸素官能基を導入することを考えた。

まず，クロロスルフィド 32 を $\mathrm{RuCl}_{2}\left(\mathrm{PPh}_{3}\right)_{3}$ 存在下べ ンゼン中 $150^{\circ} \mathrm{C}$ で加熱したところ，環化体 $33 \mathrm{a}$ と $33 \mathrm{~b}$

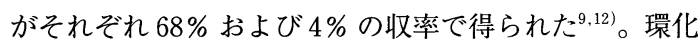
体 $33 \mathrm{a}$ と $33 \mathrm{~b}$ はフェニルチオ基の立体化学の異なる異 性体である。同様に，化合物 34 を $\mathrm{RuCl}_{2}\left(\mathrm{PPh}_{3}\right)_{3}$ で処理 したところ，環化体 $35 \mathrm{a}(48 \%)$ と $35 \mathrm{~b}$ (trace)が得られ た。

環化体 33 a,b および 35 a, b の構造上の大きな特徵 は, $33 \mathrm{a}, \mathrm{b}$ ではクロロ原子が $\alpha$ 配置(equatorial)を，ま た, $35 \mathrm{a}, \mathrm{b}$ ではクロロ原子が $\beta$ 位置( axial)をとってい
ることである。この結果はラジカル中間体 36(図 1)を考 えることによって説明できる。すなわち，36において， $\mathrm{R}=\mathrm{H}$ の場合, 空間的にすいている凸面からクロロ原子 が攻撃すると $33 \mathrm{a}, \mathrm{b}$ を与える。一方, $\mathrm{R}=\mathrm{Ph}$ の場合には, フェニル基の立体障害により凸面からの攻撃が妨げら れ，クロロ原子が凹面から攻撃することにより $35 \mathrm{a}, \mathrm{b}$ を与えたものと考えられる。

Pretazettine の合成に必要なクロロスルフィド 38 をシ クロヘキセン 37 から立体選択的に合成し，次いで，38 を $\mathrm{RuCl}_{2}\left(\mathrm{PPh}_{3}\right)_{3}$ で処理したところ，環化体 39 が $57 \%$ の収率で得られた。

化合物 39 を 40 に変換し，これをDBUで処理したと ころ，オレフィン 41 が得られた。次いで， 41 を $\mathrm{LiAlH}_{4}$ で還元し，ピバロイル化を行うと，エステル 43 が得ら れた9)。化合物 43 は，既に，Martinらにより (土)haemanthidine (44)を経て $( \pm)$-pretazettine $(45)$ へと変換 されているので，ここに pretazettine の形式合成を行う ことができた。このように，クロロスルフィド 38 の atom-transfer 環化反応を用いることにより，環化体 39 に含まれるクロロ原子およびフェニルチオ基を pretazettine 合成に必要な官能基変換にうまく利用すること ができた。 

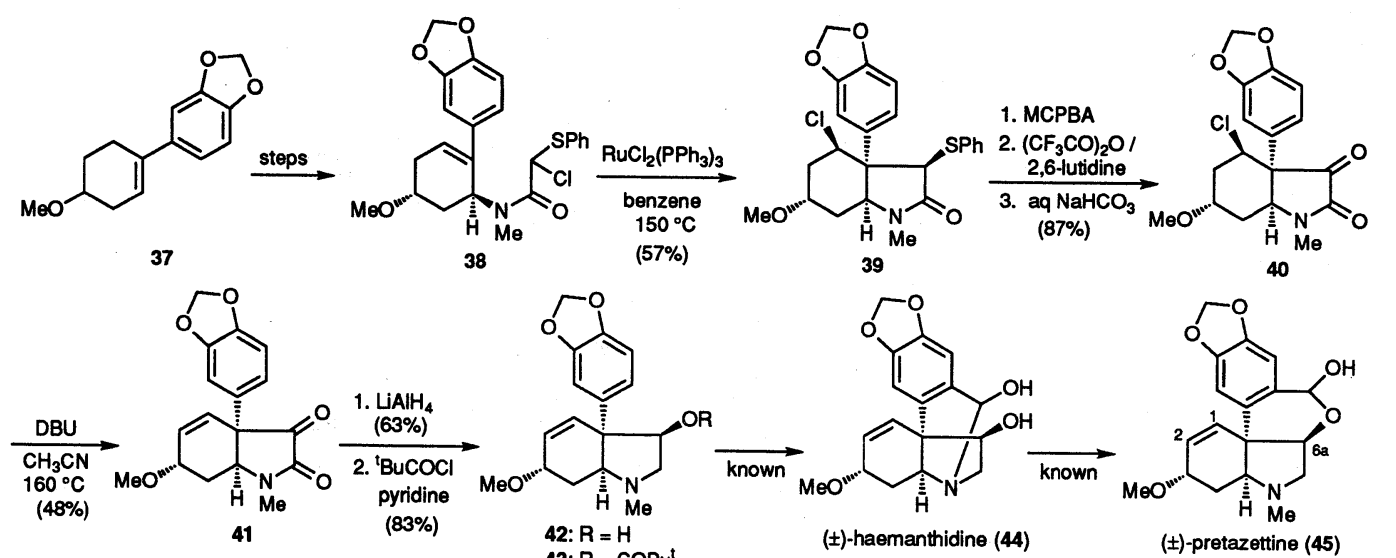

Scheme 11

\section{5-Endo-Trig 型ラジカル環化反応}

\section{1. $\gamma$-ラクタムの合成}

クロロアセトアミド $46 \mathrm{a}$ を還流トルエン中 AIBN 存 在下 $\mathrm{Bu}_{3} \mathrm{SnH}$ で処理したところ, 環化体 $47 \mathrm{a}$ と還元体 48 がそれぞれ $63 \%$ および $8 \%$ の収率で得られた。また, $46 \mathrm{~b}$ および $46 \mathrm{c}$ を同様に処理したところ, 環化体 $47 \mathrm{~b}$ $(3 \alpha-\mathrm{Me}: 3 \beta-\mathrm{Me}=6: 1)$ および $47 \mathrm{c}(3 \alpha-\mathrm{Ph}: 3 \beta-\mathrm{Ph}=2$ :3)がそれぞれ得られた ${ }^{13,14)}$ 。

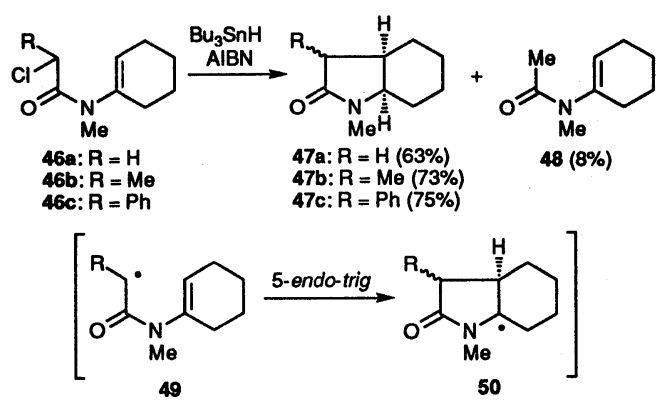

Scheme 12

化合物 47は，46 から生じたカルバモイルメチルラジ カル 49 が5-endo-trig 型の閉環反応を起こして50を与 え, 次いで, 50 が $\mathrm{Bu}_{3} \mathrm{SnH}$ の攻撃を受けることにより生 成したものと考えられる。従来，5-endo-trig 型の閉環 反応は困難とされており, 実際, ラジカル環化反応で 5-endo 型の反応に成功した例は報告されていなかった。 筆者らは,ここに, 5-endo-trig 型ラジカル環化反応の 最初の例を見いだすことができた。

ラジカル 49 が5-endo-trig 型の環化反応を行う理由を
調べるため，化合物 51 と 54 の反応を検討した。その結 果, 51 からは 5-endo-trig 型環化体 52 と 53 が得られた が，54 からは還元体 55 のみしか得られなかった。すな わち，ラジカル 49 に含まれるラクタムカルボニル基の 存在が 5-endo-trig 型反応を促進する上で必須であるこ とがわかった。しかし，このラクタムカルボニル基の役 割については今のところ定かではない。

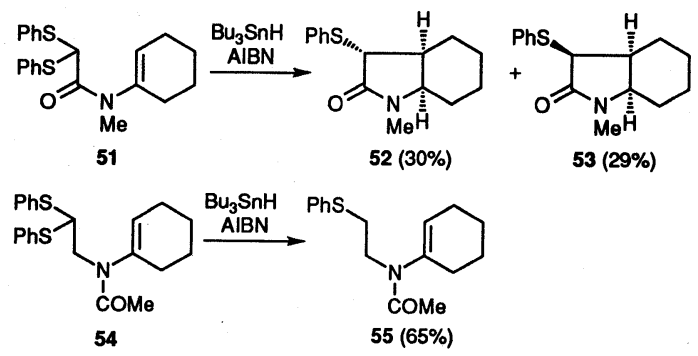

Scheme 13

次に, クロリド 56 のラジカル環化反応を検討したと ころ， $\beta$-ラクタム 57 のみが得られた ${ }^{13,14}$ 化合物 56 から 57 が生成する理由は, 56 から発生したカルバモイルメ チルラジカルの 4-exo-trig 型環化反応によって生じた中 間体 58 a のラジカル中心が隣接する芳香環によって強 く安定化を受けるためと考えられる。

一方， 7 員環をもつ化合物 59 は $\gamma$-ラク夕ム 60 のみ を与えた。分子モデルを考察すると, 59 の 4-exo 型環化 反応によって生じる中間体 $58 \mathrm{~b}$ のラジカルの $p$ 軌道は 隣接する芳香環の $\pi$ 軌道とほほ直交しており，そのた め, このラジカルは芳香環による安定化を受けないと考 えられる。したがって，50のような比較的安定な $\alpha-ア$ 


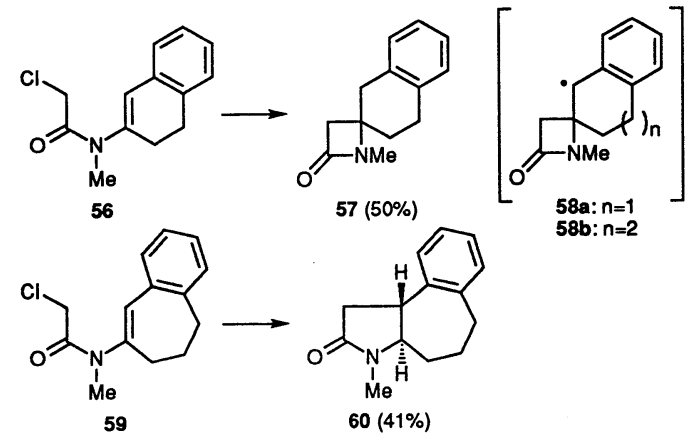

Scheme 14

シルアミノラジカルを経由して 60 が生成したものと思 われる。

\section{2. タンデムラジカル環化反応}

クロリド 61 を $\mathrm{Bu}_{3} \mathrm{SnH}$ で処理したところ，5-endo 型 閉環反応に引き続く6-endo 型閉環反応によるタンデム ラジカル環化反応が起こり, パーヒドロエリスリナン誘 導体 62 が $44 \%$ の収率で得られた ${ }^{14)} 。$

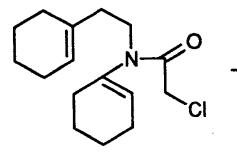

61

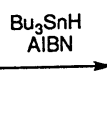

Scheme 15

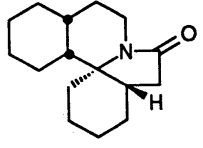

62
5.3. 5-アリール-2-ピロリドンの合成：(士)-Cotinine の合成

ジチオアセタール $63 \mathrm{a}$ を 3.3 当量の $\mathrm{Bu}_{3} \mathrm{SnH}$ で処理 したところ，64aを経て，65 a が75\% の収率で得られ た。対応するクロロアセトアミドまたはジクロロアセ卜 アミドの反応では良い結果が得られなかった。同様に， 63 b から ( \pm )-cotinine (65 b)が $97 \%$ の高収率で得られ た ${ }^{15)}$ 。

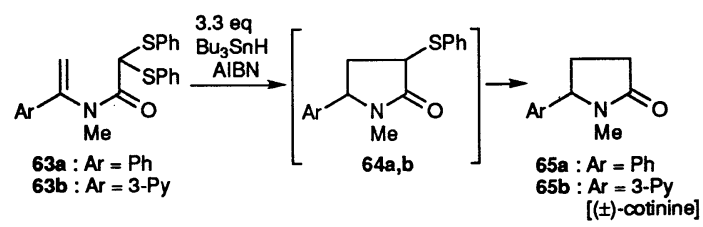

Scheme 16
6. 4-Exo-Trig 型ラジカル環化反応による $\beta$-ラ クタムの合成

\section{1.（土)-PS-5 の形式合成}

前述のように，クロロアセトアミド 56 は，芳香環に よって安定化されたラジカル中間体 58 a を経て $\beta$-ラク 夕ム57を与えた。そこで, 次に, ラジカル安定化基と してフェニルチオ基をビニル基末端に導入した化合物の 環化反応を検討した。まず，化合物 66 を還流卜ルエン 中 $\mathrm{AIBN}$ 存在下 $\mathrm{Bu}_{3} \mathrm{SnH}$ で処理したところ, $\beta$-ラクタム 67 と還元体 68 がそれぞれ $45 \%$ および $14 \%$ の収率で得 られた ${ }^{16)}$ 。 $\beta$-ラク夕ム 67 は于才基によって安定化され たラジカル中間体 $69(\mathrm{X}=\mathrm{H})$ を経由して生成したものと 考えられる。
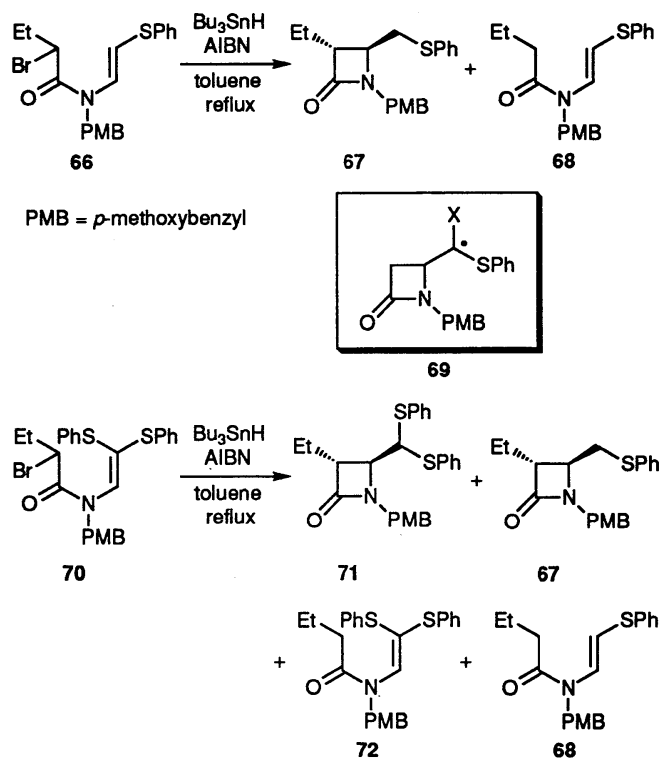

Scheme 17

一方，ビニル基末端に 2 つのフェニルチオ基を導入し た化合物 70 は $\beta$-ラクタム 71 を $58 \%$ の好収率で与え た。同時に，化合物 67 も少量得られた。化合物 67 は $\beta$-ラク夕ム 71 のチ才基が反応条件下で一部脱硫されて 生成したものと考えられる。本反応で $\beta$-ラク夕ムの収 率が向上したのは，ラジカル中間体 $69(\mathrm{X}=\mathrm{SPh})$ の高い 安定性に基づくものと考えられる。

次に, 70 から化合物 67 のみを得る目的で, $\mathrm{Bu}_{3} \mathrm{SnH}$ の量を 2 当量に増やしたところ，71(27\%)，67(18\%)押 よび $72(14 \%)$ の他に化合物 68 が $15 \%$ の収率で得られ た ${ }^{17)}$ 。化合物 72 を $\mathrm{Bu}_{3} \mathrm{SnH}$ で処理しても 68 を与えない 
ことから，68の生成機構は次のように考えられる。す なわち, $\beta$-ラク夕ム 71 のチ才基が過利のトリブチルス ズラジカルによって脱離すると, ラジカル 73 が生じる。 次いで，このラジカルに $\mathrm{Bu}_{3} \mathrm{SnH}$ が攻撃すると化合物 67 が生成するが, 一方, ラジカル 73 が $\beta$-ラク夕ム環を開 裂し, 生じたラジカル 74 が $\mathrm{Bu}_{3} \mathrm{SnH}$ の攻撃を受けるこ とにより 68 が生成したものと考えられる。実際，化合 物 71 の還流トルエン溶液に $\mathrm{Bu}_{3} \mathrm{SnH}$ と $\mathrm{AIBN}$ の混合物 をゆっくり滴下したところ, 脱硫体 67 $(27 \%)$ の他に化 合物 68 が 7\% の収率で得られた。
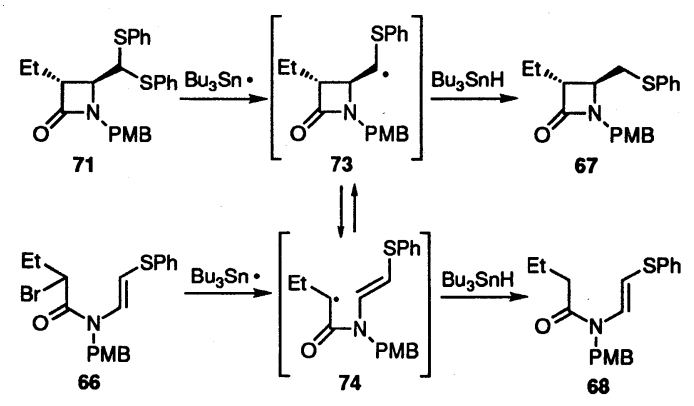

Scheme 18

ラジカル 74 はブロミド 66 の環化反応，すなわち， ラ ジカル 73 を経由して $\beta$-ラク夕ム 67 を与える反応の中 間体である。したがって，上記のように，ラジカル 73 がラジカル 74 へ開裂するということは, 74 と 73 との 閉環および開環反応が可逆性をもつということを意味す る。

化合物 67 は式 19 に示すルートを経て， $\beta$-ラクタム 系抗生物質の 1 つである $( \pm$ )-PS-5(79)の合成中間体 78 へと変換することができた ${ }^{17)}$ 。

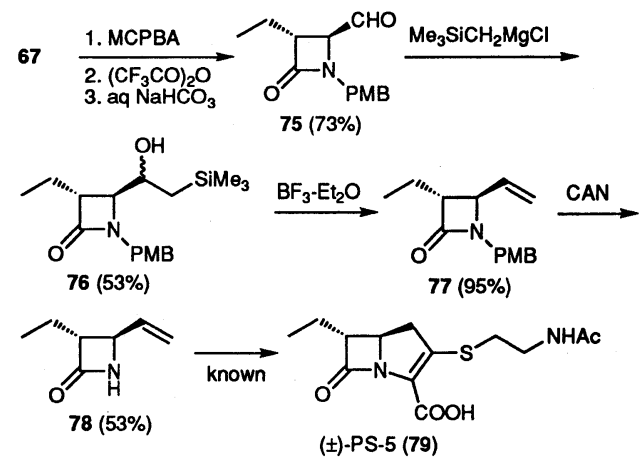

Scheme 19
6.2. 1.2-不斉誘起反応：(十)-チエナマイシンの合成

$(+)$-チエナマイシン $(88)$ の側鎖アルコールと同一の 立体化学の酸素官能基を有するブロミド 80 を-トレオ ニンから合成し，これを還流トルエシ中 AIBN 存在下 $\mathrm{Bu}_{3} \mathrm{SnH}$ で処理したところ, $(3 R, 4 R)-$ 体 81 a と $(3 S, 4 S)$-体 81 b の約 $2: 1$ の混合物が $64 \%$ の総収率で 得られた ${ }^{16)}$ 。すなわち，80の環化反応において若干の 1,2-不斉誘起が観察された。しかし, 主成績体である $81 \mathrm{a}$ の 3 位と 4 位の立体化学は, (+)-チエナマイシン

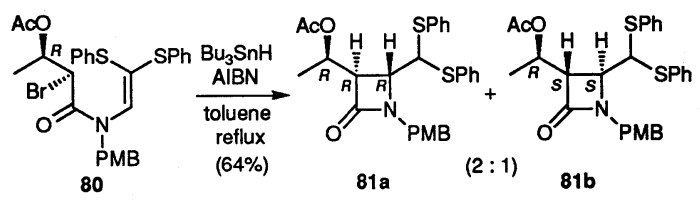

Scheme 20

(88)のそれとは逆であることがわかった。そこで，D-卜 レオニンから 82 を合成し, そのラジカル環化反応によっ て得られるであろう主成績体 $83 \mathrm{a}$ の酸素官能基を反転 させることにした。すなわち, 82 から得た $83 \mathrm{a}$ と $83 \mathrm{~b}$ の約 $2: 1$ の混合物を加水分解し, 生じたアルコール体 の混合物をへキサンー酢酸エチルから分別再結晶すると, 83 a に由来するアルコール 84 が $56 \%$ の好収率で得ら れた。次いで, 84 を $\mathrm{Bu}_{3} \mathrm{SnH}$ で処理することにより 85 とし，これを Mitsunobu 反転にかけると，アルコール 体 86 が得られた。 86 は式 21 に示すルートを経て，4アセトキシ体 87 とした ${ }^{17)}$ 。化合物 87 は既に, (+)-チ エナマイシンへと変換されているので, ここに, 不斉ラ ジカル環化反応を用いる(+)-チエナマイシンの形式合 成を行うことができた。

\subsection{1,3-不斉誘起：(+)-PS-5 の合成}

次に，窒素原子上にキラル補助基を導入した化合物の ラジカル環化反応における1,3-不斉誘起について検討 した。すなわち, 窒素原子上に $(S)-1$-フェネチル基を 有するブロミド 89 を還流ベンゼン中 AIBN 存在下 $\mathrm{Bu}_{3} \mathrm{SnH}$ で処理したところ, $(4 S)$-体 $90 \mathrm{a}$ と $(4 R)$-体 $90 \mathrm{~b}$ の $2.4: 1$ の混合物が $69 \%$ の収率で得られた ${ }^{18)}$ 。化合物

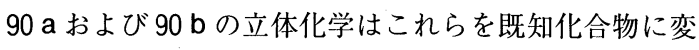
換することにより決定した。

$(4 S)$-体 90 a が優先的に得られる理由については定 かではないが, 1 つの可能性として, ブロミド 89 から 発生したカルバモイルメチルラジカル 91 のアミド結合 を二重結合に見立てた Felkin-Anh モデルを考察する と, (S)-1 フェネチル基の好ましい配座は図 2 のよう になる。ここで, ラジカルがビニル基を攻撃する際, 


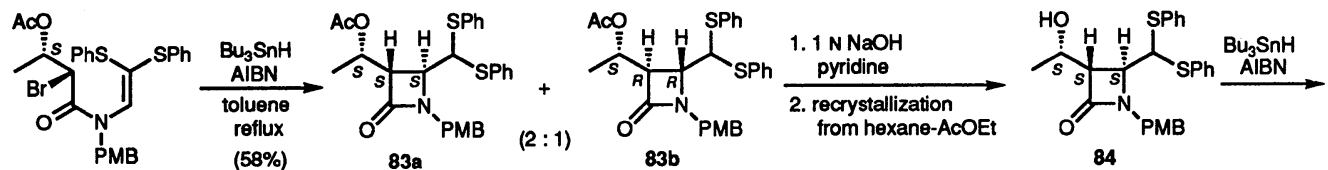

82

(58\%) $83 \mathrm{a}$

83b

84

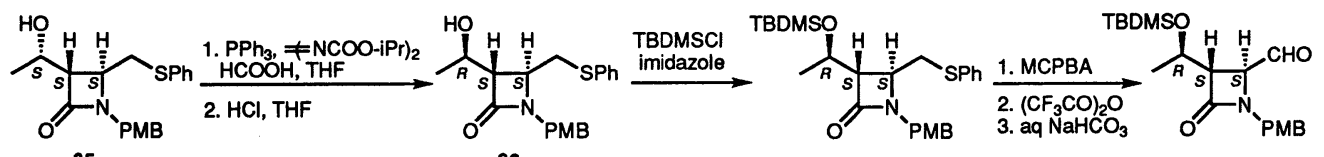

86

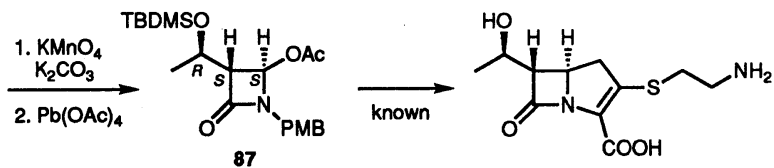

(+)-thienamycin (88)

Scheme 21

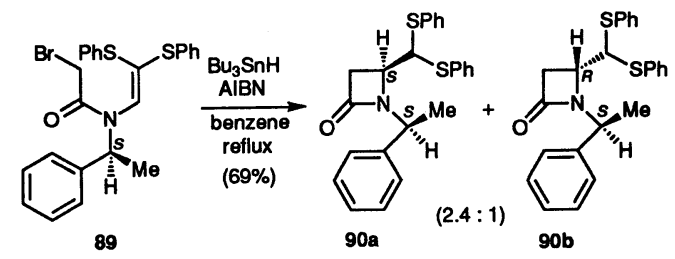

Scheme 22
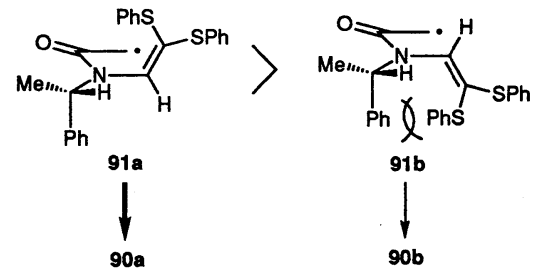

91 b のようにビニル基が下面を向くと, フェネチル基 のフェニル基とビニル基末端のフェニルチオ基との間に 立体反発が生じる。そのため, より立体障害の少ない 91 a 経て環化反応が進行し, $(4 S)$-体 90 a が主成績 体として得られたものと考えられる。

次に, 化合物 92 を還流ベンゼン中 $\mathrm{Bu}_{3} \mathrm{SnH}$ で处理し たところ, $(3 R, 4 S)$-体 93 a と $(3 S, 4 R)$-体 93 b の 2.3 $: 1$ の混合物が $77 \%$ の収率で得られた。本反応を還流 トルエン中で行うと, 収率は $70 \%$ と若干低下するが, $93 \mathrm{a}, \mathrm{b}$ の比は $3.4: 1$ と向上した。次に, $93 \mathrm{a}, \mathrm{b}$ の混合 物を $\mathrm{Bu}_{3} \mathrm{SnH}$ で処理すると, カラム精製後, $94 \mathrm{a}$ と $94 \mathrm{~b}$ がそれぞれ $48 \%$ および $9 \%$ の収率で得られた。化合物 94 a は式 23 に示すルートを経て, (+)-PS-5(79)の合 成中間体 95 へと変換することができた ${ }^{18)}$ 。

Fig. 2
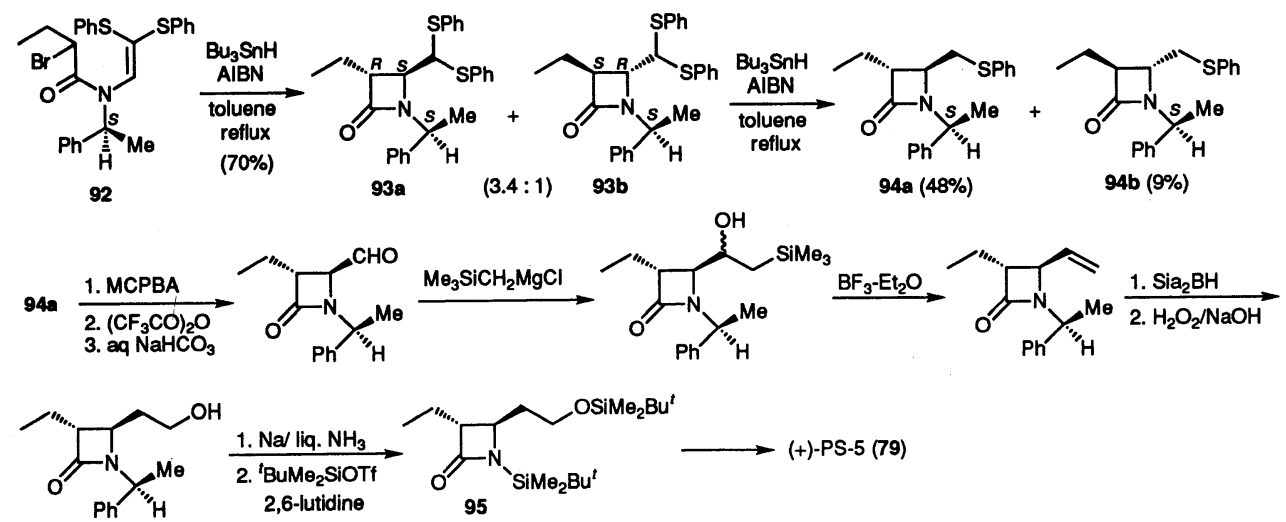

Scheme 23 
前述のプロミド 82 の 1,2-不斉誘起と 92 の 1, 3-不斉 誘起を組み合わせれば, 高い選択性で $(4 S)-2$-アゼチジ ノンが得られることが期待される。そこで, プロミド 96 の環化反応を検討した。その結果, 本反応を還流べ ンゼン中で行うと， $40 \%$ の収率で $97 \mathrm{a}, \mathrm{b}$ の混合物が $3.5: 1$ の比で得られ, また, 還流卜ルエン中で行うと, 収率は $29 \%$ と低下するが, $7.5: 1$ の高い選択性で $97 \mathrm{a}$ と $97 \mathrm{~b}$ が得られることがわかった ${ }^{19)}$ 。次いで, $97 \mathrm{a}, \mathrm{b}$ の混合物を加水分解し, カラム精製を行うと 98 a が $47 \%$ の収率で得られた。さらに, $98 \mathrm{a}$ を $\mathrm{Bu}_{3} \mathrm{SnH}$ で処 理することにより 99 とし，これを Mitsunobu 反転にか けると, アルコール100が高収率で得られた。化合物 100 は (+)-チエナマイシン $(88)$ の有用な合成中間体と なろう。

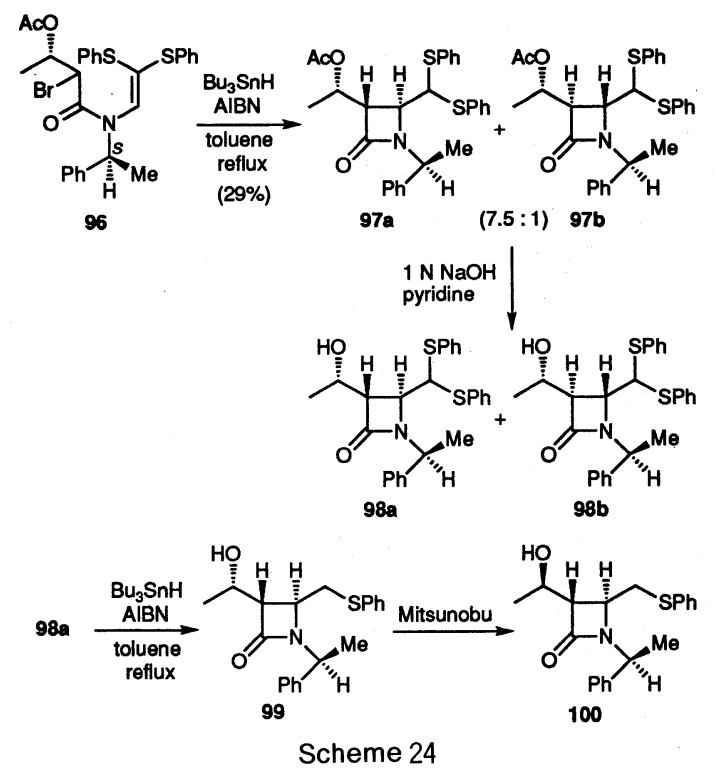

\section{6-Exo および 7-Endo 型ラジカル環化反応}

(S)-(ー)-プロリノールより合成した $\alpha$-セレネニル アミド $101 \mathrm{a}, \mathrm{b}$ の混合物 $(3.7: 1)$ を還流トルエン中 AIBN 存在下 $\mathrm{Bu}_{3} \mathrm{SnH}$ で処理したところ, $101 \mathrm{a}$ に由来す る 6-exo 型㧍よび7-endo 型環化体 102 と 103 がそれぞ れ 43\% および $17 \%$ の収率で得られた ${ }^{20)}$ 。101b に由来 する環化体は未確認である。環化体 102 はインドリジジ ンアルカロイドの 1 つである(+)-ipalbidine(105)の合 成中間体 104 へと導くことができた。

\section{7-Exo および 8-Endo 型ラジカル環化反応}

o-アリルー- - クロロアセトアニリド類 106 の環化反応

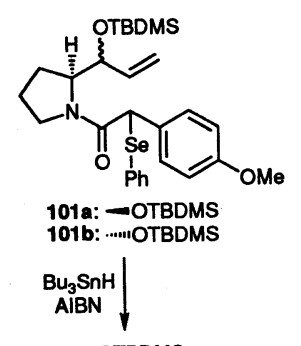

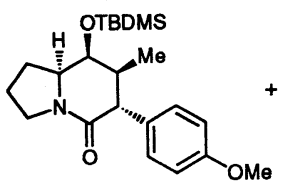

$102(43 \%)$
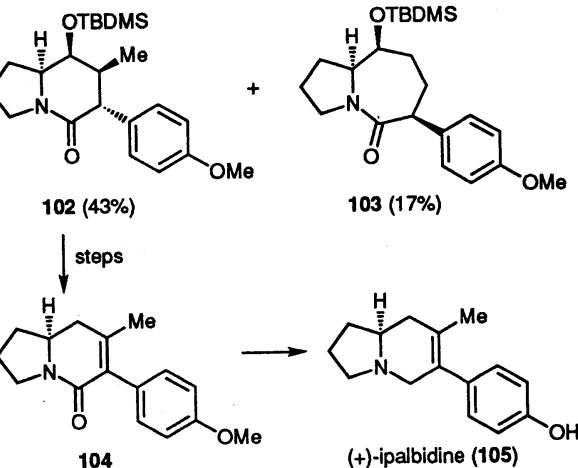

$103(17 \%)$

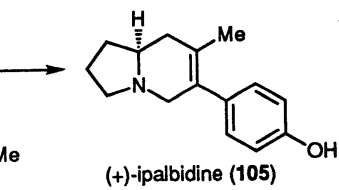

Scheme 25 は，一般に，7-exo 環化体 107 と 8-endo 環化体 109 の混 合物を与えた $(\mathrm{R}=\mathrm{H}: 38 \% / 44 \%, \mathrm{R}=\mathrm{Me}: 58 \% / 36 \%$, $\mathrm{R}=\mathrm{Ph}: 23 \% / 63 \%)^{21)}$ 。しかし, ジクロロ体 106 $(\mathrm{R}=\mathrm{Cl})$ は 2.2 当量の $\mathrm{Bu}_{3} \mathrm{SnH}$ 存在下 7-exo 環化体 $107(\mathrm{R}=\mathrm{H})$ の みを与え, ジチオアセタール 108 は 1.1 当量の $\mathrm{Bu}_{3} \mathrm{SnH}$ 存在下 8-endo 環化体 $109(\mathrm{R}=\mathrm{SPh})$ のみを与えた。この ように, ラジカル炭素上の置換基を種々変えると, その 環化反応のコース(7-exo/8-endo)が変化することがわ かった。しかし，これらの結果を明快に説明することは 今のところできない。

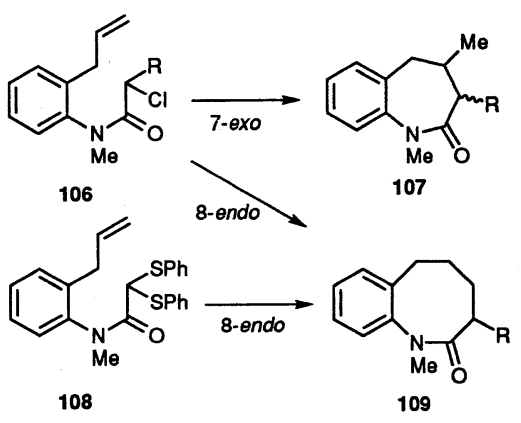

Scheme 26

9. おわりに

以上のように， $\alpha$-ハロまたは $\alpha$-チオアミド1より発 生させたカルバモイルメチルラジカル 2 は, 分子内アル 
ケンとの反応で 4-exo 型から 8-endo 型に至る多様な環 化反応を起こして, 種々の含窒素複素環化合物を与える ことが明らかとなった。特に強調すべきは，N-ビニル$\alpha$-ハロアミドの 5-endo および 4-exo 型環化反応であろ う。共に難かしい環化様式であるにもかかわらず，ビ二 ル基末端の置換基を変えることにより, その雨者の反応 のコースを制御することができた。また，7-exo および 8-endo 型反応にみられるように, ラジカル炭素上の置 換基を変えることによっても，その環化の方向が制御さ れることもわかった。

最近の研究の急速な進歩とともに「ラジカル環化反応」 は, 今や, 研究する時代から使う時代になってきたかも しれない。たた，「ラジカル環化反応における立体化学 の制御」はこれからの大きな課題の 1 つであろう。 $\beta$-ラ クタムの合成の項で述べたように, 筆者らも還流ベンゼ ンあるいはトルエン中でも, 高いジアステレオ選択性(不 斉誘起)が発現することを見いだした。より適切なキラ ル補助基の選択は, ラジカル環化反応を合成化学的にさ らに利用価値の高いものとすることであろう。

おわりに，本研究遂行に際し惜しま努力をはらわれ た学生諸氏に深く感謝の意を表します。

(平成 6 年 9 月 1 日受理)

\section{文献}

1) B. Giese, "Radicals in Organic Synthesis : Formation of Carbon-Carbon Bonds," Pergamon Press, Oxford, 1986 ; D.P. Curran, Synthesis, 1988, 417, 489; C.P. Jasperse, D.P. Curran, T.L. Fevig, Chem . Rev., 91, 1237 (1991)

2) 大嶌幸一郎, 内本喜一朗, 有合化, 47, 40 (1989)

3) (a) M. Mori, Y. Kubo, Y. Ban, Heterocycles, 31，433 (1990), および引用文献：(b) H. Nagashima, N. Ozaki, M. Ishii, K. Seki, M. Washiyama, K. Itoh, J. Org, Chem., 58, 464 (1992), および引用文献

4) H. Ishibashi, T. Sato, M. Irie, S. Harada, M. Ikeda, Chem. Lett., 1987, 795

5) T. Sato, Y. Wada, M. Nishimoto, H. Ishibashi, M. Ikeda, J. Chem. Soc., Perkin Trans. 1, 1989, 879

6) gem-ジアルキル効果を考慮した $N$-無置換の $N$-プ ロパギルー $\alpha$-ブロモアミドはラジカル環化反応成
績体を与える[J.M. Clough, G. Pattenden, P.G. Wight, Tetrahedron Lett. , 30, 7469 (1989)]。また, $N$-アリルトリクロロアセトアミドのルテニウム触 媒環化反応では $7 \mathrm{~d}$ に相当する環化体が得られる : 文献 3 b) 参照。

7) Curran らによっても同様の議論がなされている。 V. Snieckus, J.-C. Cuevas, C.P. Sloan, H. Liu, D.P. Curran, J. Am. Chem. Soc., 112, 896 (1990) ; D.P. Curran, A.C. Abraham, H. Liu, J. Org. Chem. , 56, 4335 (1991)

8) T. Sato, K. Tsujimoto, K. Matsubayashi, H. Ishibashi, M. Ikeda, Chem. Pharm. Bull., 40, 2308 (1992)

9) H. Ishibashi, N. Uemura, H. Nakatani, M. Okazaki, T. Sato, N. Nakamura, M. Ikeda, J. Org. Chem., 58, 2360 (1993)

10) H. Ishibashi, T.S. So, T. Sato, K. Kuroda, M. Ikeda, J. Chem. Soc., Chem. Commun., 1989, 762

11) H. Ishibashi, T.S. So, K. Okochi, T. Sato, N. Nakamura, M. Ikeda, J. Org. Chem., 56, 95 (1991)

12) H. Ishibashi, H. Nakatani, S. Iwami, T. Sato, N. Nakamura, J. Chem. Soc., Chem. Commun., 1989, 1767

13) H. Ishibashi, N. Nakamura, T. Sato, M. Takeuchi, M. Ikeda, Tetrahedron Lett. , 32, 1725 (1991)

14) T. Sato, N. Nakamura, K. Ikeda, M. Okada, H. Ishibashi, M. Ikeda, J. Chem. Soc., Perkin Trans. 1, 1992, 2399

15) T. Sato, N. Machigashira, H. Ishibashi, M. Ikeda, Heterocycles, 33, 139 (1992)

16) H. Ishibashi, C. Kameoka, A. Yoshikawa, R. Ueda, K. Kodama, T. Sato, M. Ikeda, Synlett, 1993, 649

17) H. Ishibashi, C. Kameoka, H. Iriyama, K. Koda ma, T. Sato, M. Ikeda, J. Org. Chem., in press

18) H. Ishibashi, C. Kameoka, T. Sato, M. Ikeda, Synlett, 1994, 445

19）石橋弘行, 亀岡千里, 览玉和也, 佐藤達典, 池田 正澄, 第 20 回反応と合成の進歩シンポジウム(静 岡)講演要旨集, p.375 (1994)

20) 石橋弘行, 鹿浦次郎, 前川典子, 佐藤達典, 池田 正澄, 日本薬学会第 114 年会(東京)講演要旨集 2 , p.10 (1994)

21) T. Sato, S. Ishida, H. Ishibashi, M. Ikeda, $J$. Chem. Soc., Perkin Trans. 1, 1991, 353 